Article

\title{
Dynamic and Heterogeneous Demand for Urban Green Space by Urban Residents: Evidence from the Cities in China
}

\author{
Tianzheng Zhang ${ }^{1}{ }^{\oplus}$, Yingxiang Zeng ${ }^{1}$, Yingjie Zhang ${ }^{1, *}$, Yan Song ${ }^{2}$ and Hongxun $\mathrm{Li}^{1}$ \\ 1 School of Economics and Management, Beijing Forestry University, Beijing 100083, China; \\ zh_tz@bjfu.edu.cn (T.Z.); zengyx_0701@163.com (Y.Z.); lihongxun2002@163.com (H.L.) \\ 2 Department of City and Regional Planning, University of North Carolina at Chapel Hill, \\ Chapel Hill, NC 27599, USA; ys@email.unc.edu \\ * Correspondence: zyj2015@bjfu.edu.cn
}

Received: 1 October 2020; Accepted: 7 November 2020; Published: 11 November 2020

\begin{abstract}
With the increasing number of people starting to attach importance to urban green space (UGS), estimating urban residents' demand for UGS has become critical. Previous studies have estimated residents' demands for UGS in different cities using the Rosen-Roback model. However, there has been little analysis of the renters' requirements for UGS or the dynamic and heterogeneous demands for UGS by residents in cities with varying characteristics. In this study, the prefecture-level cities in China were selected as the object of study for their wide representation of various city characteristics, and the Rosen-Roback model was used to address the abovementioned issues. Residents' demand for UGS in 285 prefecture-level cities was assessed from 2010 to 2017. The results confirm our hypothesis that when UGS increases by $1 \%$, house prices will increase by about $3 \%$ and rents will increase by about $7 \%$, and the demand continues to grow. We also analyzed the heterogeneous demands for UGS by urban residents in different types of cities from three aspects: population density, economic level, and the effects of the National Forest City policy. Finally, we provided suggestions based on empirical results for planning and managing UGS.
\end{abstract}

Keywords: urban green space; dynamic demand; heterogeneous demand; home buyer; renter

\section{Introduction}

Urban green spaces (UGSs) are the foundation of the urban ecosystem, which provide opportunities for a wide range of leisure, sports, and recreational activities [1-3]. Properly planned and managed UGS can improve the urban environment, as well as contribute to urban residents by providing physical and psychological benefits [4-9]. UGSs located in or near urban residential areas have received widespread attention due to its relevance to the living environment and health of residents $[10,11]$. Therefore, estimating the demand for UGS by urban residents is essential for better identifying and understanding its benefits, which can facilitate the demand-oriented planning of UGS.

Using the Rosen-Roback model, previous studies have shown that the amenities in cities have a positive impact on the local house prices, confirming that urban residents need amenities such as UGS [12-15]. Nevertheless, previous studies have focused primarily on the impact on house prices in a few cities and/or over a short period of time [16-18]. Moreover, little attention has been devoted to the impact on rent or the dynamic and heterogeneous demand by residents across different cities $[19,20]$. Renters have demands for houses and the surrounding UGSs that differ from those of home buyers [21,22]. If only considering the demand for UGS by house buyers, the results cannot fully reflect the preferences of most residents in the housing market $[23,24]$. Thus, it is essential to assess the 
demand for UGS by home buyers and renters more appropriately using data with improved spatial and/or temporal coverage and attacking the dynamic changes and heterogeneity issues.

Prefecture-level cities in China are an ideal object to address the abovementioned issue, as they represent a wide range of city characteristics, which is a result of the development of China's real estate market $[25,26]$. In 2020, the National Bureau of Statistics of China reported an urbanization rate of $60.60 \%$, which indicates that more than $60 \%$ of the population lives in urban areas. Furthermore, the green area rate of urban built-up areas is $41.1 \%$, while the green park area per capita is only 13.7 $\mathrm{m}^{2}$, well below the United Nations' (U.N.) standard of $60 \mathrm{~m}^{2}$ for the best living environment [26]. These problems have weakened the ecological function of UGS and aroused widespread public concern about its protection and management [27].

The primary objective of this study was to analyze the dynamic and heterogeneous demands for UGS by home buyers and renters through the Rosen-Roback model using data from 285 prefecture-level cities in China from 2010 to 2017. The rest of this paper unfolds as follows. Section 2 reports the materials and methods. Section 3 introduces the results of the basic findings and the dynamic and heterogeneous demand for UGS by house buyers and renters across different cities. Section 4 includes a discussion on the heterogeneity of demand, policy implications, and research limitations. Section 5 presents the main conclusion.

\section{Materials and Methods}

\subsection{Conceptual Framework}

The Rosen-Roback model illustrates how differences in productivity and amenities among cities determine differences in house prices and wages [24,28]. We used the Rosen-Roback model to estimate the demand for UGS by urban residents for factors that have an impact on housing prices, which include the treatment variables and urban characteristics. With the Rosen-Roback model, the marginal price of UGS, or willingness to pay(WTP), can be identified, thus achieving a monetized measure of residents' demand for UGS [29]. The following example of our empirical analysis is for city $i$ observed in year $t$, and our study period is from 2010 to 2017. The Rosen-Roback model is applied as shown in Model (1).

$$
H P_{i t}=\beta_{0}+\beta_{11} U G S_{i t}+\cdots+\beta_{1 i} X_{i t}+\varphi_{i}+\varepsilon_{i t}
$$

where $H P_{i t}$ is the average house price of city $i$ in year $t, U G S_{i t}$ is the level of UGS of the city $i$ in year $t, X_{i t}$ is the control variable, $\varphi_{i}$ is the city fixed effect, and $\varepsilon_{i t}$ is the error term. $\beta_{0}$ is a constant term, $\beta_{11}$ captures the marginal price of UGS, and the coefficients of $\beta_{1 i}$ to be estimated represent the contribution of $X_{i t}$ to house prices. Moreover, we set the significance level at alpha $=0.1,0.05$, and 0.01 to test the reliability of results.

We formulate three hypotheses to be tested. First, renters and home buyers have a heterogeneous demand for UGS. Second, there exist dynamic changes in residents' demands for UGS over the study period. Third, residents in cities with different characteristics have a heterogeneous demand for UGS. The empirical model based on the Rosen-Roback model above (as shown in Model (1)) is adjusted to verify these three hypotheses.

To identify the heterogeneous demands for UGS by renters and home buyers, $H P_{i t}$ is replaced with the local rent price $\left(R E N T_{i t}\right)$ in Model (2), which is based on the same control variable $X_{i t}$. The coefficient of $U G S_{t}$ represents the renters' WTP for UGS. Comparing the results of Model (1) to Model (2) reveals the heterogeneous demands of renters and buyers. The expectation is that home buyers will care more about UGS than the house renters because the former may be more concerned about the quality of life.

$$
\operatorname{RENT}_{i t}=\beta_{0}+\beta_{21} U G S_{i t}+\cdots+\beta_{2 i} X_{i t}+\varphi_{i}+\varepsilon_{i t}
$$


To evaluate the dynamic in residents' requirements from 2010 to 2017, the interaction term Time $* U G S_{i t}$ is used. The dummy variable Time represents the observation period, and the samples are divided into two observation periods, which are from 2010 to 2013 and from 2014 to 2017. Time $=1$ represents the observation period from 2014 to 2017, and Time $=0$ represents the observation period from 2010 to 2013. $\beta_{31}$ denotes the difference between the marginal price of UGS from 2014 to 2017 and that from 2010 to 2013. We expect to find that the demand for UGS by urban residents has continuously increased because people's concern for it may increase every year, in which case, $\beta_{31}$ would be positive and statistically significant.

$$
H P_{i t}=\beta_{0}+\beta_{31} \text { Time } * U G S_{i t}+\beta_{32} U G S_{i t}+\cdots+\beta_{3 i} X_{i t}+\varphi_{i}+\varepsilon_{i t}
$$

Considering the heterogeneous demand for UGS by residents in cities with different characteristics, we divide the cities into two groups based on their population density (the population density in this paper is calculated by dividing the total population of the municipal district by the land area of the municipal district), gross domestic product (GDP), and whether the city has been designated as a National Forest City. We first divide the cities into two groups based on population density, that is, high and low population densities. Then, we use the dummy variable $D \_D e n s i t y$ to indicate the level of the population density of a city. Specifically, $D \_D e n s i t y=1$ represents a city with a high population density, and $D \_D e n s i t y=0$ represents a city with a low population density. An interaction term between $U G S_{i t}$ and D_Density is added in Model (4), which is based on controlling for the factor $X_{i t}$. Then, we perform a first-order derivation of Model (4) to obtain Equation (5). In Equation (5), $\beta_{41}$ represents the difference between the WTP of residents in cities with high and low population densities, $\beta_{42}$ represents the WTP of residents in cities with low population densities, and $\beta_{41}+\beta_{42}$ represents the WTP of residents in cities with high population densities. We expect that the WTP of residents in cities with high population densities would be larger than that in cities with low population densities, in which case, $\beta_{41}$ would be positive. A possible explanation is that the UGS is a scarce resource in cities with higher population densities, which leads to rising marginal prices of UGS. The same approach is applied to analyze the heterogeneous demands of residents in cities with different economic levels and to evaluate differences between cities with and without the National Forest Cities designation.

$$
\begin{gathered}
H P_{i t}=\beta_{0}+\beta_{41} D_{p} * U G S_{i t}+\beta_{42} U G S_{i t}+\beta_{43} D_{p}+\cdots+\beta_{4 i} X_{i t}+\varphi_{i}+\varepsilon_{i t} \\
\text { The WTP for UGS }=\frac{\partial H P_{i t}}{\partial U G S_{i t}}=\beta_{41} D_{p}+\beta_{42}
\end{gathered}
$$

\subsection{Definition of Variables and Basic Descriptive Statistics}

Our dataset included the treatment variables of UGS, the urban characteristics, and dummy variables for city classification. First, we defined UGS from two dimensions, which were the quantity and quality of the park area. The park area (TPA) represents the total area of parks, and the per capita park area (PPA) represents the quality of the park area. The urban characteristics mainly refer to two aspects, namely, economic level and population size. The local economic level is one of the key factors that affect housing prices and rent. Per capita GDP (PGDP) was selected to represent the urban economic level. Household income reflects the purchasing power of households, which directly affects housing transactions. Per capita disposable income (DI) was selected to represent household income. We also controlled for real estate investment (REI), which represents the scale of a city's real estate supply in the future and has an important impact on the scale of real estate supply and the relation between market supply and demand [30]. Next, the population size was incorporated, as it reflects the demand of the real estate market. A city with a large population size may have a shortage of housing resources, thereby raising house prices. The permanent resident population (POP) was selected to represent the population size. Finally, the dummy variables (D_Density, D_GDP, and D_NFC) were 
defined to distinguish different urban characteristics, including population density, GDP, and whether the city is a National Forest City.

We obtained panel data from 285 prefecture-level cities from 2010 to 2017 to evaluate the impacts of UGS on house prices and rents across cities. The data sources were China City Statistical Yearbooks for 2011-2018, China Urban Construction Statistical Yearbooks for 2011-2018, and the statistical yearbooks of each province. To reduce the impacts of heteroscedasticity and skewness, we used the logarithmic values of HP, RENT, PGDP, POP, DI, and REI. The definitions and descriptive statistics of the main variables are shown in Table 1.

Table 1. Variable definitions and descriptive statistics.

\begin{tabular}{|c|c|c|c|c|c|}
\hline Type & Variable & Definition & Obs. & Mean & St. Dev. \\
\hline Dependent variable & LnHP & $\begin{array}{c}\text { Logarithm of local house prices } \\
\left.\text { (yuan } / \mathrm{m}^{2}\right)\end{array}$ & 2280 & 8.44 & 0.45 \\
\hline \multirow{3}{*}{ Independent variable } & LnRENT & $\begin{array}{l}\text { Logarithm of local house rental prices } \\
\text { (yuan } / \mathrm{m}^{2} / \text { month) }\end{array}$ & 2280 & 2.56 & 0.37 \\
\hline & LnTPA & Logarithm of park area (hectare) & 2280 & 6.79 & 1.00 \\
\hline & $\operatorname{LnPPA}$ & $\begin{array}{l}\text { Logarithm of per capita park area } \\
\qquad\left(\mathrm{m}^{2} / \text { person }\right)\end{array}$ & 2280 & 2.15 & 0.63 \\
\hline \multirow{9}{*}{ Control variable } & LnPGDP & $\begin{array}{c}\text { Logarithm of per capita GDP } \\
\text { (yuan/person) }\end{array}$ & 2280 & 10.60 & 0.58 \\
\hline & $\operatorname{LnPOP}$ & $\begin{array}{l}\text { Logarithm of the permanent resident } \\
\text { population }(10,000 \text { people) }\end{array}$ & 2280 & 4.65 & 0.78 \\
\hline & $\operatorname{LnDI}$ & $\begin{array}{l}\text { Logarithm of per capita disposable } \\
\text { income (yuan/person) }\end{array}$ & 2280 & 9.79 & 0.24 \\
\hline & $\operatorname{LnREI}$ & $\begin{array}{c}\text { Logarithm of real estate investment } \\
(10,000 \text { yuan })\end{array}$ & 2280 & 13.45 & 1.42 \\
\hline & D_Density & $\begin{array}{l}\text { Dummy variable indicating whether } \\
\text { cities are high population density: } 1 \\
\text { for high population density, } 0 \text { for low }\end{array}$ & 2280 & 0.50 & 0.50 \\
\hline & D_GDP & $\begin{array}{l}\text { economic level of cities: } 1 \text { for a high } \\
\text { economic level, } 0 \text { for low }\end{array}$ & 2280 & 0.50 & 0.50 \\
\hline & & $\begin{array}{l}\text { Dummy variable indicating whether } \\
\text { cities have been designated as }\end{array}$ & & & \\
\hline & $D \_N F C$ & $\begin{array}{l}\text { National Forest Cities: } 1 \text { for a city that } \\
\text { is designated as a National Forest }\end{array}$ & 2280 & 0.22 & 0.42 \\
\hline & & City, 0 for a city that is not designated. & & & \\
\hline
\end{tabular}

\subsection{Descriptive Statistics of the Spatial Heterogeneity}

Figure 1 shows that cities with lower housing prices and rents are concentrated in the north. Cities with higher house prices and rents are concentrated in the southeast coastal areas with higher population densities and economic levels and include Shanghai, Jiangsu, Zhejiang, and Fujian. However, cities with higher rents are also concentrated in the central region and include Hubei, Hunan, and Guangxi.

In Figure 2, it is readily apparent that parks are more densely distributed in the east than in the west. Cities with relatively larger park areas are located in eastern China, especially in the southeast coastal area. In contrast to Figure 1; Figure 2, we found that cities with higher population densities and economic levels, such as Shanghai, Jiangsu, and Zhejiang, tend to have larger park areas. Therefore, we inferred that residents in cities with higher population densities and economic levels may have a higher demand for UGS than those in cities with lower population density and economic levels. 


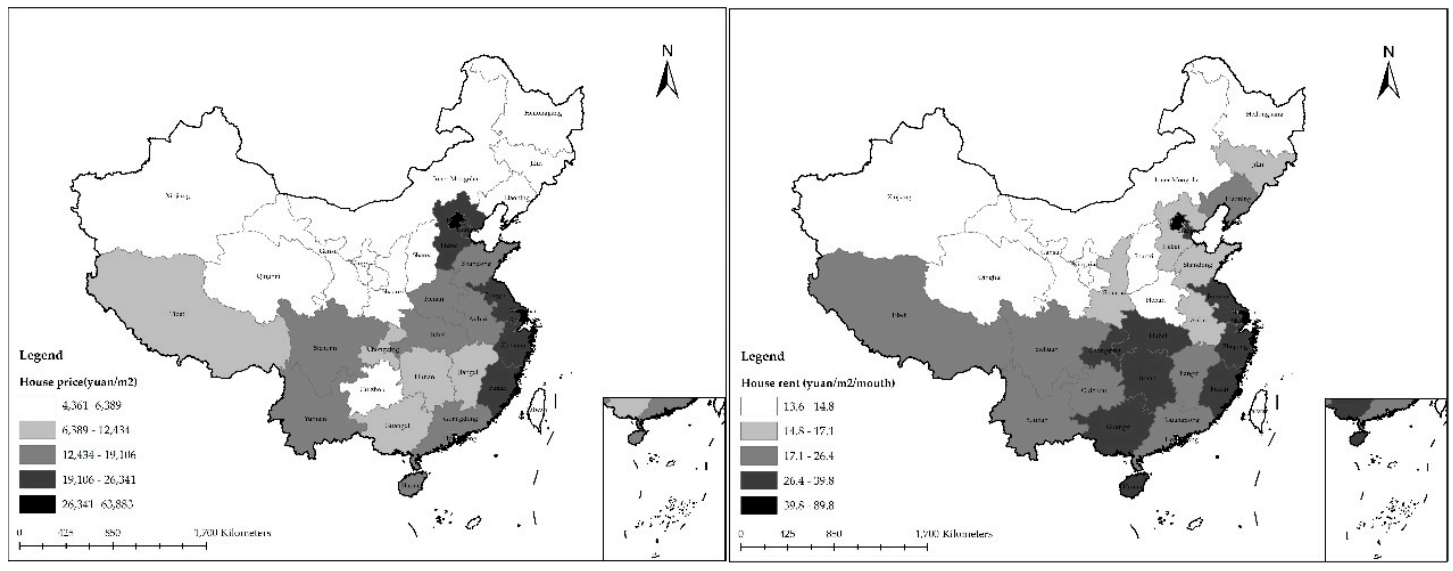

Figure 1. Spatial distribution of urban house prices (left) and rent (right) in 2017.

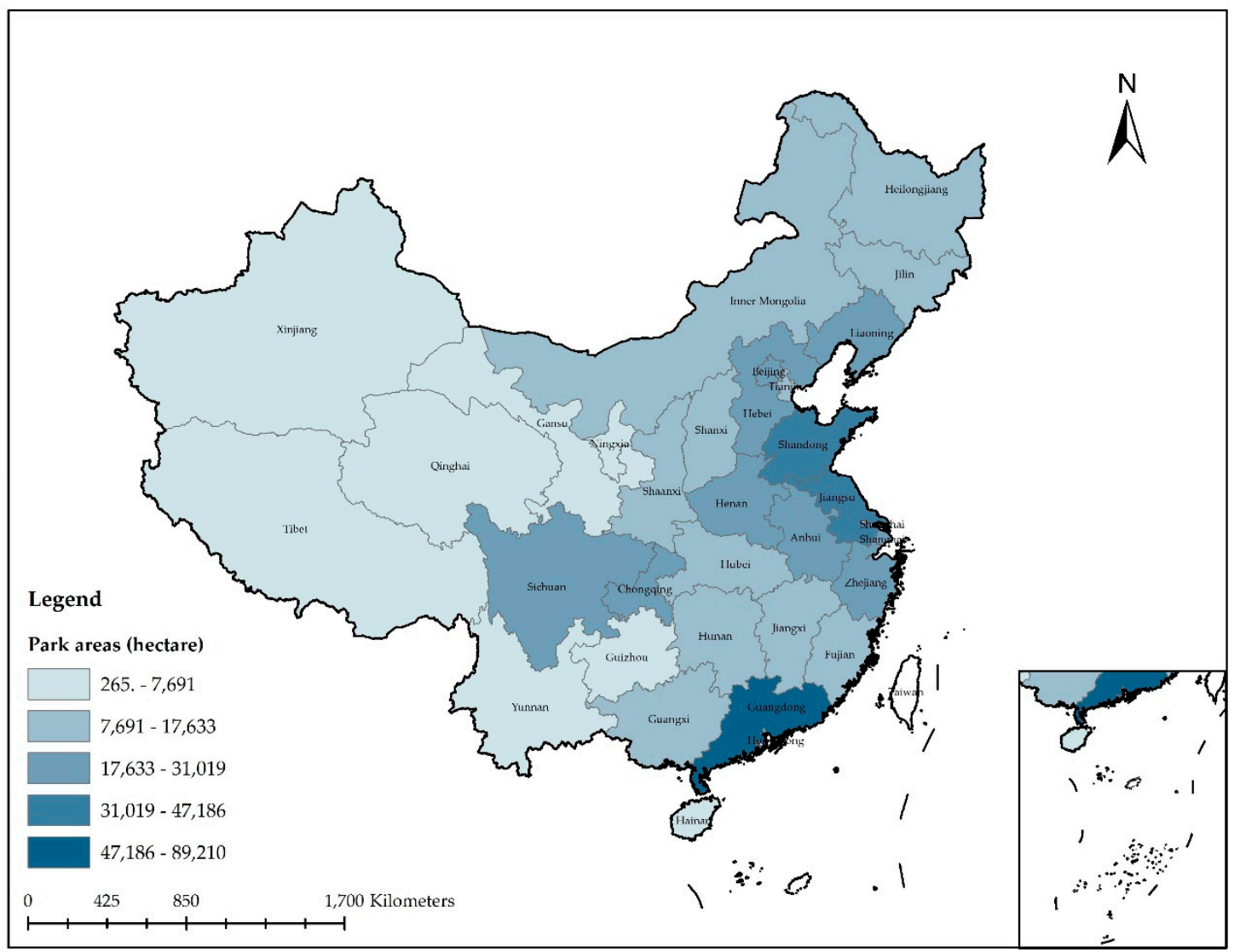

Figure 2. Spatial distribution of urban park areas in 2017.

Furthermore, we divided cities into two groups based on population density and GDP. Figure 3 shows that the park area in different types of cities has continued to grow, with significant differences in the park areas between cities at different population densities and economic levels. The cities with high population densities and economic levels have larger park areas than cities with low population densities and economic levels. 

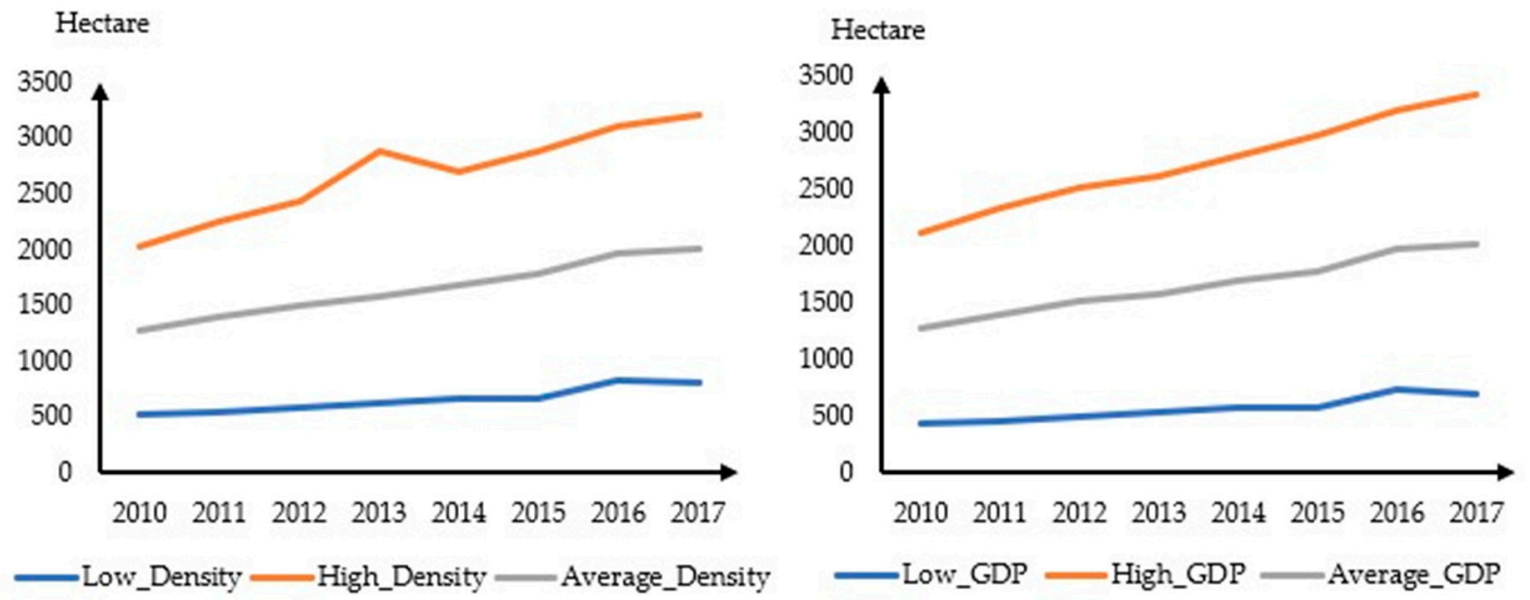

Figure 3. The dynamics of park areas in cities with different population densities (left) and economic level (right). GDP: gross domestic product.

\section{Results}

\subsection{The Demand for UGS by Home Buyers}

The key empirical results of the benchmark Rosen-Roback model are shown in Table 2, with standard errors in parentheses. The result of the Hausman model is listed in Table A1. It was found that fixed effects are more accurate than random effects in Model (1).

Table 2. Empirical regression results of the impact of urban green space (UGS) on housing prices.

\begin{tabular}{|c|c|c|c|c|}
\hline & (1) & (2) & (3) & (4) \\
\hline & LnHP & LnHP & LnHP & LnHP \\
\hline LnTPA & $\begin{array}{c}0.069^{* * * *} \\
(0.02)\end{array}$ & $\begin{array}{c}0.033^{* *} \\
(0.01)\end{array}$ & & \\
\hline LnPPA & & & $\begin{array}{c}0.026^{* *} \\
(0.01)\end{array}$ & $\begin{array}{c}0.030 * * \\
(0.01)\end{array}$ \\
\hline LnPGDP & & $\begin{array}{c}0.134^{* * *} \\
(0.03)\end{array}$ & & $\begin{array}{c}0.135^{* * *} \\
(0.03)\end{array}$ \\
\hline LnPOP & & $\begin{array}{c}0.099 * * * \\
(0.03)\end{array}$ & & $\begin{array}{c}0.128^{* * *} \\
(0.03)\end{array}$ \\
\hline$L n D I$ & & $\begin{array}{l}0.019 \\
(0.03)\end{array}$ & & $\begin{array}{l}0.019 \\
(0.03)\end{array}$ \\
\hline LnREI & & $\begin{array}{c}0.028^{* * * *} \\
(0.01)\end{array}$ & & $\begin{array}{c}0.029 * * * \\
(0.01)\end{array}$ \\
\hline Constant & $\begin{array}{c}7.970 * * * \\
(0.11)\end{array}$ & $\begin{array}{c}5.768^{* * *} \\
(0.44)\end{array}$ & $\begin{array}{c}8.380 * * * \\
(0.03)\end{array}$ & $\begin{array}{c}5.770 * * * \\
(0.44)\end{array}$ \\
\hline City-fixed effect & yes & yes & yes & yes \\
\hline Observations & 2280 & 2280 & 2280 & 2280 \\
\hline $\mathrm{F}$ & 19.398 & 17.436 & 3.938 & 17.454 \\
\hline Between- $\mathrm{R}^{2}$ & 0.486 & 0.562 & 0.139 & 0.562 \\
\hline
\end{tabular}

Note: ${ }^{* *} p<0.05 ; * * * p<0.01$.

Columns (1) and (3) show the estimated results without the control variables, and columns (2) and (4) show the estimated results with them. Our results show that even after controlling for other factors, the coefficients of LnTPA and LnPPA are all positive and significant, which indicates that UGS has a positive impact on house prices. To maximize $\mathrm{R}^{2}$, we used the results that were estimated by adding control variables. Column (2) shows that the coefficient of $L n T P A$ is 0.033 , which means that when the park area increases by $1 \%$, the house price increases by $3.3 \%$. Column (4) shows that the coefficient of $L n P P A$ is 0.030 , which means that when the per capita park area increases by $1 \%$, the house price 
increases by $3.0 \%$. In columns (2) and (4), the coefficients of $L n P G D P$, LnPOP, and $L n R E I$ are all positive and significant at the level of $1 \%$.

\subsection{The Demand for UGS by Renters}

The empirical regression results for the impact of UGS on house rents are presented in Table 3. The results of the Hausman model are listed in Table A2. It was also found that fixed effects are more accurate than random effects in Model (2).

Table 3. Empirical regression results of the impact of UGS on house rents.

\begin{tabular}{|c|c|c|c|c|}
\hline & (1) & (2) & (3) & (4) \\
\hline & LnRENT & LnRENT & LnRENT & LnRENT \\
\hline LnTPA & $\begin{array}{c}0.083^{* * *} \\
(0.02)\end{array}$ & $\begin{array}{c}0.070 * * * \\
(0.02)\end{array}$ & & \\
\hline$L n P P A$ & & & $\begin{array}{c}0.102 \text { *** } \\
(0.02)\end{array}$ & $\begin{array}{c}0.072^{* * *} \\
(0.02)\end{array}$ \\
\hline LnPGDP & & $\begin{array}{c}0.145^{* * *} \\
(0.03)\end{array}$ & & $\begin{array}{c}0.144^{* * *} \\
(0.03)\end{array}$ \\
\hline LnPOP & & $\begin{array}{c}0.079^{* * * *} \\
(0.02)\end{array}$ & & $\begin{array}{l}0.011 \\
(0.02)\end{array}$ \\
\hline $\operatorname{LnDI}$ & & $\begin{array}{c}0.188^{* * *} \\
(0.03)\end{array}$ & & $\begin{array}{c}0.187^{* * *} \\
(0.03)\end{array}$ \\
\hline$L n R E I$ & & $\begin{array}{c}0.044^{* * *} \\
(0.01)\end{array}$ & & $\begin{array}{c}0.044^{* * *} \\
(0.01)\end{array}$ \\
\hline Constant & $\begin{array}{c}2.378^{* * *} \\
(0.04)\end{array}$ & $\begin{array}{c}-1.930^{* * * *} \\
(0.43)\end{array}$ & $\begin{array}{c}1.862^{* * *} \\
(0.12)\end{array}$ & $\begin{array}{c}-1.928^{\text {**** }} \\
(0.43)\end{array}$ \\
\hline City-fixed effect & yes & yes & yes & yes \\
\hline Observations & 2280 & 2280 & 2280 & 2280 \\
\hline $\mathrm{F}$ & 24.171 & 34.281 & 35.913 & 35.047 \\
\hline Between- $\mathrm{R}^{2}$ & 0.138 & 0.600 & 0.484 & 0.599 \\
\hline
\end{tabular}

To test the first hypothesis in Section 2.2, we used Model (2) to estimate the impact of UGS on rent. Columns (1) and (3) show the estimated results without the control variables, and columns (2) and (4) show the estimated results with them. The results show that even after controlling for other factors, the coefficients of LnTPA and LnPPA are all positive and significant at the level of $1 \%$, which indicates that UGS has a positive impact on rents. To maximize $\mathrm{R}^{2}$, we used the results that were estimated by adding control variables. Column (2) shows that the coefficient of LnTPA is 0.070 , which indicates that when the park area increases by $1 \%$, rent increases by $7 \%$. Column (4) shows that the coefficient of LnPPA is 0.072 , which indicates that when the per capita park area increases by $1 \%$, rent increases by $7.2 \%$. In columns (2) and (4), the coefficients of LnPGDP, LnDI, and LnREI are all positive.

\subsection{Dynamic Changes in the Demand for UGS by Urban Residents}

To test the second hypothesis in Section 2.2, we calculated the dynamic change in WTP for UGS by urban residents from 2010 to 2017 using Model (3). The coefficients of the interaction terms Time ${ }^{*}$ LnTPA and Time ${ }^{*}$ LnPPA represent the dynamic change in urban residents' demands for UGS. The dummy variable Time represents the period of observation, and samples are divided into two periods, namely, from 2010 to 2013 and from 2014 to 2017.

The results for dynamic changes in urban residents' WTP for UGS are provided in Table 4. Columns (1) and (2) show the dynamic changes in home buyers' WTP for UGS. The coefficient of Time ${ }^{*} \operatorname{LTPA}$ is 0.001 but not significant, and the coefficient of Time* $\operatorname{*} P P A$ is 0.008 . The coefficients of LnTPA and LnPPA are positive. Therefore, the coefficient of Time ${ }^{*} L n P P A$ shows that home buyers' WTP for the per capita park area from 2014 to 2017 is higher than that from 2010 to 2013. Columns (3) 
and (4) show the dynamic changes in renters' WTP for UGS, and the coefficients of Time ${ }^{*}$ LTPA and Time ${ }^{*} n P P A$ are also positive and significant at the levels of $1 \%$. The positive coefficients show that renters' WTP for park areas and per capita park areas from 2014 to 2017 is higher than that from 2010 to 2013. Therefore, the empirical results show that the WTP for UGS from 2014 to 2017 is higher than that from 2010 to 2013 for both home buyers and renters.

Table 4. Dynamic changes in urban residents' WTP for UGS.

\begin{tabular}{|c|c|c|c|c|}
\hline & (1) & (2) & (3) & (4) \\
\hline & $\operatorname{LnHP}$ & LnHP & LnRENT & LnRENT \\
\hline Time $^{*} \operatorname{LnTPA}$ & $\begin{array}{l}0.001 \\
(0.01)\end{array}$ & & $\begin{array}{c}0.008^{* * *} \\
(0.01)\end{array}$ & \\
\hline LnTPA & $\begin{array}{c}0.028^{* *} \\
(0.01)\end{array}$ & & $\begin{array}{c}0.027 * \\
(0.02)\end{array}$ & \\
\hline Time* $\operatorname{LnPPA}$ & & $\begin{array}{c}0.008^{* * *} \\
(0.01)\end{array}$ & & $\begin{array}{c}0.021^{* * *} \\
(0.01)\end{array}$ \\
\hline LnPPA & & $\begin{array}{c}0.027^{*} \\
(0.02)\end{array}$ & & $\begin{array}{l}0.028 \\
(0.02)\end{array}$ \\
\hline Constant & $\begin{array}{c}5.782^{* * *} \\
(0.44)\end{array}$ & $\begin{array}{c}5.771^{* * * *} \\
(0.44)\end{array}$ & $\begin{array}{c}-1.793^{* * *} \\
(0.42)\end{array}$ & $\begin{array}{c}-1.910 \text { *** } \\
(0.43)\end{array}$ \\
\hline Control variables & yes & yes & yes & yes \\
\hline City-fixed effect & yes & yes & yes & yes \\
\hline Observations & 2280 & 2280 & 2280 & 2280 \\
\hline $\mathrm{F}$ & 16.647 & 16.647 & 32.005 & 29.594 \\
\hline Between- $\mathrm{R}^{2}$ & 0.561 & 0.561 & 0.544 & 0.558 \\
\hline
\end{tabular}

\subsection{Heterogeneous Demand for UGS by Urban Residents}

\subsubsection{Heterogeneous Demand for UGS by Urban Residents in Cities with Different Population Densities}

Population density may reflect the pressure of the population on UGS, but it also indicates the level of urban residents' demand for UGS. According to the dynamic of park areas in cities with different population densities, as mentioned in Section 3.2, cities with high population densities have larger park areas than cities with low population densities. This phenomenon may indicate that residents in cities with higher population densities have a higher demand for UGS. Therefore, the demand for UGS by urban residents in cities with different population densities may vary. We divided the cities into two groups_-high and low population densities_-and used the dummy variable D_Density to indicate if a city has a high population density.

The results for the heterogeneous demand for UGS by urban residents in cities with different population densities are provided in Table 5. To test the third hypothesis in Section 2.2, the coefficients of the interaction terms were used to represent the difference between the WTP for UGS by residents in cities with high and low population densities. Column (1) shows that the coefficient of D_Density*LnTPA is 0.054 , which indicates that home buyers in cities with high population densities have a higher WTP for park areas than those in cities with low population densities. Column (2) shows that the coefficient of D_Density*LnPPA is positive but not significant; thus, the difference between the WTP of home buyers for the per capita park areas in cities with high and low population densities is not significant. Column (3) shows that the coefficient of D_Density ${ }^{*}$ LnTPA is -0.032 , which indicates that renters in low-population-density cities have a higher WTP for park areas than those in high-population-density cities. Column (4) shows that the coefficient of D_Density ${ }^{*}$ LnPA is -0.042 , which indicates that renters in low-population-density cities have a higher WTP for per capita park areas than those in cities with high population densities. In summary, home buyers in cities with high population densities have a higher WTP for UGS than those in cities with low population densities, and house renters 
in cities with low population densities have a higher WTP for UGS than those in cities with high population densities.

Table 5. The impact of UGS on house prices and rent in cities with different population densities.

\begin{tabular}{|c|c|c|c|c|}
\hline & (1) & (2) & (3) & (4) \\
\hline & LnHP & LnHP & LnRENT & LnRENT \\
\hline D_Density*LnTPA & $\begin{array}{c}0.054^{* * *} \\
(0.02)\end{array}$ & & $\begin{array}{c}-0.032 \text { * } \\
(0.02)\end{array}$ & \\
\hline LnTPA & $\begin{array}{l}0.013 \\
(0.01)\end{array}$ & & $\begin{array}{c}0.084^{* * *} \\
(0.02)\end{array}$ & \\
\hline D_Density ${ }^{*} \ln P P A$ & & $\begin{array}{l}0.034 \\
(0.02)\end{array}$ & & $\begin{array}{c}-0.042 \text { ** } \\
(0.02)\end{array}$ \\
\hline LnPPA & & $\begin{array}{l}0.018 \\
(0.01)\end{array}$ & & $\begin{array}{c}0.087^{* * * *} \\
(0.02)\end{array}$ \\
\hline D_Density & $\begin{array}{c}-0.391 \text { *** } \\
(0.13)\end{array}$ & $\begin{array}{c}-0.090 * \\
(0.05)\end{array}$ & $\begin{array}{l}0.223 \\
(0.13)\end{array}$ & $\begin{array}{c}0.095 * \\
(0.05)\end{array}$ \\
\hline Constant & $\begin{array}{c}5.905^{* * *} \\
(0.44)\end{array}$ & $\begin{array}{c}5.749 * * * \\
(0.44)\end{array}$ & $\begin{array}{c}-2.005^{* * *} \\
(0.43)\end{array}$ & $\begin{array}{c}-1.895^{* * *} \\
(0.43)\end{array}$ \\
\hline Control variables & yes & yes & yes & yes \\
\hline City-fixed effect & yes & yes & yes & yes \\
\hline Observations & 2280 & 2280 & 2280 & 2280 \\
\hline $\mathrm{F}$ & 14.740 & 14.390 & 25.986 & 25.559 \\
\hline Between- $\mathrm{R}^{2}$ & 0.597 & 0.571 & 0.579 & 0.587 \\
\hline
\end{tabular}

Note: ${ }^{*} p<0.1 ;{ }^{* *} p<0.05 ;{ }^{* * *} p<0.01$

3.4.2. Heterogeneous Demand for UGS by Urban Residents in Cities with Different Economic Levels

Economic levels may affect the availability of local green infrastructure and, in turn, the level of UGS. According to the dynamics of park areas in cities with different economic levels, as mentioned in Section 3.2, cities with high economic levels have larger park areas than cities with low economic levels. This phenomenon may indicate that residents in cities with a higher economic level have a higher demand for UGS. Therefore, the demand for UGS by urban residents in cities with different economic levels may vary. We divided the cities into two groups-high and low economic levels based on the GDP—and used the dummy variable D_GDP to indicate if the city has a high economic level.

The results for the heterogeneous demand for UGS by urban residents in cities with different economic levels are provided in Table 6. To test the third hypothesis in Section 2.2, the coefficients of the interaction terms were used to represent the difference between residents' WTP for UGS in cities with high and low economic levels. Column (1) shows that the coefficient of D_GDP* LnTPA is 0.045, which indicates that home buyers in cities with high economic levels have a higher WTP for park areas than those in cities with low economic levels. Column (2) shows that the coefficient of $D_{-} G D P^{*} \operatorname{LnPPA}$ is positive but not significant; thus, the difference between home buyers' WTP for per capita park areas in cities with high and low economic levels is not significant. Column (3) shows that the coefficient of D_GDP*LnTPA is -0.044 but not significant; thus, the difference between renters' WTP for park areas in cities with high and low economic levels is not significant. Column (4) shows that the coefficient of D_GDP* ${ }^{*}$ nPPA is -0.047 , which indicates that renters in cities with low economic levels have a higher WTP for per capita park areas than those in cities with high economic levels. In summary, home buyers in cities with high economic levels have a higher WTP for UGS than those in cities with low economic levels, and renters in cities with low economic levels have a higher WTP for UGS than those in cities with high economic levels. 
Table 6. The impact of UGS on house prices and rent in cities with different economic levels.

\begin{tabular}{ccccc}
\hline & $\mathbf{( 1 )}$ & $\mathbf{( 2 )}$ & $\mathbf{( 3 )}$ & $\mathbf{( 4 )}$ \\
\hline \multirow{2}{*}{ D_GDP*LnTPA } & LnHP & LnHP & LnRENT & LnRENT \\
& $0.045^{*}$ & & -0.039 & \\
LnTPA & $(0.03)$ & & $(0.02)$ & \\
& 0.017 & & $0.085^{* * *}$ & \\
D_GDP*LnPPA & $(0.01)$ & & $(0.02)$ & \\
& & & & $-0.047^{* *}$ \\
LnPPA & & 0.019 & & $(0.02)$ \\
& & $(0.02)$ & & $0.087^{* * *}$ \\
D_GDP & $0.024^{*}$ & $(0.01)$ & & $(0.02)$ \\
& $(0.17)$ & -0.034 & 0.250 & $0.092^{*}$ \\
Constant & $5.845^{* * *}$ & $5.788^{* * *}$ & $-1.997^{* * *}$ & $-1.949^{* * *}$ \\
Control variables & $(0.45)$ & $(0.45)$ & $(0.44)$ & $(0.44)$ \\
City-fixed effect & yes & yes & yes & yes \\
Observations & yes & yes & yes & yes \\
F & 2280 & 2280 & 2280 & 2280 \\
Between-R ${ }^{2}$ & 13.392 & 13.274 & 25.071 & 24.763 \\
\hline
\end{tabular}

Note: ${ }^{*} p<0.1 ;{ }^{* *} p<0.05 ;{ }^{* * *} p<0.01$.

3.4.3. Heterogeneous Demand for UGS by Urban Residents in the Designated National Forest Cities and Other Cities

UGS is a typical urban green infrastructure, and the local government plays a leading role in planning and managing it through environmental policy [31]. The National Forest City policy (in 2004, the State Forestry Administration and the National Greening Committee of China launched the National Forest City Selection and Recommendation Campaign to improve the urban living environment by promoting and protecting the urban green space; there are 194 Chinese cities that have been officially designated as the National Forest Cities at the end of 2019), as a key environmental policy of China, can significantly improve UGS and thus contribute to the improvement of the urban living environment [32]. Cities with better living environments may raise house prices and rent [4]. Therefore, the National Forest City policy may affect the demand of urban residents for UGS. In this analysis, we divided the cities into two groups, namely, cities with and without the National Forest City designation, and used the dummy variable $D \_N F C$ to indicate whether a city has been designated as the National Forest City.

The results for heterogeneous demand for UGS by urban residents in cities with and without the National Forest City designation are provided in Table 7. To test the third hypothesis in Section 2.2, the coefficients of the interaction terms were used to represent the difference in residents' WTP for UGS between cities with and without the National Forest City designation. Column (1) shows that the coefficient of $D \_N F C^{*}$ LnTPA is 0.034 , which indicates that home buyers in National Forest Cities have a higher WTP for park areas than those in cities without the designation. Column (2) shows that the coefficient of $D \_N F C^{*} L n P P A$ is positive but not significant; thus, the difference between home buyers' WTP for per capita park areas in cities with and without the National Forest City designation is not significant. Column (3) shows that the coefficient of D_NFC* ${ }^{*} n T P A$ is -0.044 , which indicates that renters in cities that have not been designated as National Forest Cities have a higher WTP for park areas than those in designated cities. Column (4) shows that the coefficient of $D \_N F C^{*} L n P P A$ is -0.078 , which indicates that renters in cities that have not been designated as National Forest Cities have a higher WTP for per capita park areas than those in the designated cities. Therefore, home buyers in the National Forest Cities have a higher WTP for UGS than those in cities without the designation, 
and renters in cities that have not been designated as National Forest Cities have a higher WTP for UGS than those in the designated cities.

Table 7. The impact of UGS on house prices and rent in cities with and without the National Forest City designation.

\begin{tabular}{|c|c|c|c|c|}
\hline & (1) & (2) & (3) & (4) \\
\hline & $\operatorname{LnHP}$ & $\mathrm{LnHP}$ & LnRENT & LnRENT \\
\hline$D \_N F C^{*} \operatorname{LnTPA}$ & $\begin{array}{c}0.034 \text { * } \\
(0.02)\end{array}$ & & $\begin{array}{c}-0.044^{* * *} \\
(0.01)\end{array}$ & \\
\hline LnTPA & $\begin{array}{l}0.019 \\
(0.01)\end{array}$ & & $\begin{array}{c}0.076^{* * *} \\
(0.02)\end{array}$ & \\
\hline$D \_N F C^{*} \operatorname{LnPPA}$ & & $\begin{array}{l}0.014 \\
(0.03)\end{array}$ & & $\begin{array}{c}-0.078^{* *} \\
(0.03)\end{array}$ \\
\hline $\operatorname{LnPPA}$ & & $\begin{array}{l}0.021 \\
(0.01)\end{array}$ & & $\begin{array}{c}0.080^{* * *} \\
(0.02)\end{array}$ \\
\hline$D \_N F C$ & $\begin{array}{c}-0.208 \text { * } \\
(0.13)\end{array}$ & $\begin{array}{l}0.002 \\
(0.07)\end{array}$ & $\begin{array}{c}0.331^{* * *} \\
(0.10)\end{array}$ & $\begin{array}{c}0.202^{* * *} \\
(0.07)\end{array}$ \\
\hline Constant & $\begin{array}{c}5.836^{* * *} \\
(0.45)\end{array}$ & $\begin{array}{c}5.859^{* * *} \\
(0.45)\end{array}$ & $\begin{array}{c}-1.805^{* * *} \\
(0.42)\end{array}$ & $\begin{array}{c}-1.720 * * * \\
(0.41)\end{array}$ \\
\hline Control variables & yes & yes & yes & yes \\
\hline City-fixed effect & yes & yes & yes & yes \\
\hline Observations & 2280 & 2280 & 2280 & 2280 \\
\hline $\mathrm{F}$ & 12.958 & 13.274 & 27.537 & 28.221 \\
\hline Between- $\mathrm{R}^{2}$ & 0.553 & 0.565 & 0.590 & 0.591 \\
\hline
\end{tabular}

Note: ${ }^{*} p<0.1 ;{ }^{* *} p<0.05 ;{ }^{* * *} p<0.01$.

The results in this section validate the hypotheses that the demand for UGS by urban residents is heterogeneous between cities. Home buyers in cities with high population densities and economic levels have a higher WTP for UGS than those in cities with low population densities and economic levels, while renters in cities with low population densities and economic levels have a higher WTP for UGS than those in cities with high population densities and economic levels. In addition, we assessed the impact of the National Forest City policy on the demand for UGS by urban residents. Home buyers in the National Forest Cities have higher WTP for UGS than those in cities without the designation, while renters in cities that have not been designated as National Forest Cities have a higher WTP for UGS than those in the designated cities.

\section{Discussion}

\subsection{Residents' Demand for UGS across Cities: Home Buyers vs. Renters}

Our key findings are derived from the results of benchmark models, which confirm that there are positive demands for UGS and that their demands are growing stronger. Specifically, after adding the control variables, when UGS increases by $1 \%$, house prices increase by about $3.0 \%$, and rents increase by about 7\%. Moreover, the results also show that the demands for UGS from 2014 to 2017 were higher than those from 2010 to 2013 for both home buyers and renters. These indicate that the price elasticity of demand for UGS by renters is higher than that of home buyers, suggesting that renters may be more sensitive to changes in UGS [33,34].

Furthermore, we confirm that there indeed exists a heterogeneous demand for UGS by house buyers and renters from three aspects: population density, economic level, and the effect of National Forest City policy. It was found that home buyers in cities with high population densities and economic levels have a higher WTP for UGS than those in cities with low population densities and economic levels, and vice versa for renters. These outcomes have to do with the fact that home buyers in cities with high population densities and economic levels are more concerned with the quality of life than renters, while renters in cities with high population densities and economic levels are more concerned 
with the convenience of living. In addition, it was revealed that the National Forest City policy has a pronounced effect on residents' demands for UGS. Home buyers in National Forest Cities have a higher WTP for UGS than those in cities without the designation, and vice versa for renters.

\subsection{Policy Implication}

Our findings also provide policymakers with important information regarding how to formulate and implement sound policies. Overall, the results provide evidence of the positive demand for UGS by urban residents. Meanwhile, improvement in UGS can not only help promote the quality of living, but it can also contribute to attracting talents and businesses [35-39]. This is critical to maintaining a city's vitality $[40,41]$ and achieving sustainability [42]. Therefore, the Chinese government should coordinate the relationship between economic development and ecological protection. In the process of urbanization, they should take a new path of high-quality development guided by ecological priority and green development.

The planning of UGS by governments should maximize social benefits in accordance with the interests and preferences of residents [9]. Considering the heterogeneous demand for UGS, the Chinese government should supply UGS based on different biophysical and socioeconomic conditions of particular cities [26,43]. Meanwhile, to ensure the economic feasibility of implementation, the government can also subsidize high urban greening financing costs through a series of suitable value capture strategies [44]. Not only can the management cost be cut down by public municipalities, but the features of the park may also be renovated or improved to better match the demands of residents $[38,42,44-46]$.

\subsection{Limitations}

Several limitations of our research need to be addressed. First, this paper addresses the dynamic and heterogeneous demands of urban residents for UGS through empirical analysis but cannot fully explain the underlying driving mechanism behind it. Second, UGS is calculated on the basis of the total area of parks, and the UGS quality is evaluated by the per capita park area. Thus, dimensions of measurement are relatively simple and may not fully reflect the conditions of UGS. Third, this study only focused on the market demand for UGS and ignored social issues such as unbalanced green space among cities. We aim to tackle these challenges in future studies.

\section{Conclusions}

These empirical results have broad academic and policy implications. First, we advanced the understanding of the estimation of residents' demand for UGS by addressing some of the underlying technical issues with more adequate data and models. In light of our research, it is no longer appropriate to ignore the heterogeneous demand for UGS by residents when anyone attempts to evaluate the demand for UGS. Considering the benefits of UGS, it is crucial to provide a path for the planning and management of UGS in cities with different characteristics to advance the sustainable development of UGS through a market-oriented approach and more efficient supply.

Author Contributions: Conceptualization, Y.Z. (Yingjie Zhang), Y.S., and H.L.; data curation, T.Z.; formal analysis T.Z.; funding acquisition, H.L. and Y.Z. (Yingjie Zhang); methodology, Y.Z. (Yingjie Zhang) and T.Z.; project administration, Y.Z. (Yingjie Zhang) and H.L.; resources, Y.Z. (Yingjie Zhang), T.Z., and Y.Z. (Yingxiang Zeng); Writing-Original draft, T.Z. and Y.Z. (Yingxiang Zeng); Writing-Review and editing, Y.Z. (Yingxiang Zeng), T.Z., Y.S., and Y.Z. (Yingjie Zhang). All authors have read and agreed to the published version of the manuscript.

Funding: This research was supported by the Fundamental Research Funds for the Central Universities (No. 2019BLRD11), the National Natural Science Foundation of China (No. 71603024), and the National Social Science Fund of China (No: 20CGL064).

Conflicts of Interest: The authors declare no conflict of interest. 


\section{Appendix A}

Table A1. Hausman test result for the house price model.

\begin{tabular}{|c|c|c|c|c|}
\hline Variable & $\mathrm{Fe}$ & $\operatorname{Re}$ & Difference & S.E. \\
\hline$L n P P A$ & 0.020 & 0.012 & 0.008 & \\
\hline LnPGDP & 0.195 & 0.210 & -0.014 & 0.005 \\
\hline LnPOP & 0.057 & 0.113 & -0.057 & 0.007 \\
\hline$L n D I$ & 0.017 & 0.073 & -0.055 & 0.002 \\
\hline LnREI & 0.022 & 0.030 & -0.009 & . \\
\hline \multicolumn{5}{|c|}{$\begin{array}{l}\mathrm{b}=\text { consistent under Ho and Ha; obtained from xtreg } \\
\text { aconsistent under Ha, efficient under Ho; obtained from xtreg } \\
\text { Test: Ho: difference in coefficients not systematic } \\
\qquad \mathrm{X}^{2}(5)=38.5 \text {; Prob }>\mathrm{X}^{2}=0.000\end{array}$} \\
\hline
\end{tabular}

Table A2. Hausman test result for the house rent model.

\begin{tabular}{ccccc}
\hline Variable & Fe & Re & Difference & S.E. \\
\hline LnPPA & 0.039 & 0.022 & 0.017 & 0.002 \\
LnPGDP & 0.116 & 0.132 & -0.015 & 0.007 \\
LnPOP & -0.008 & 0.055 & -0.062 & 0.010 \\
LnDI & 0.199 & 0.237 & -0.038 & 0.006 \\
LnREI & 0.049 & 0.058 & -0.009 & 0.001 \\
B $=$ inconsistent under Ha, efficient under Ho; obtained from xtreg \\
\multicolumn{5}{c}{ Test: Ho: difference in coefficients not systematic } \\
\multicolumn{5}{c}{$\mathrm{X}^{2}(5)=164.55$; Prob $>\mathrm{X}^{2}=0.000$} \\
\hline
\end{tabular}

\section{References}

1. Kabisch, N.; Qureshi, S.; Haase, D. Human-environment interactions in urban green spaces-A systematic review of contemporary issues and prospects for future research. Environ. Impact Assess. Rev. 2015, 50, $25-34$. [CrossRef]

2. Sanesi, G.; Chiarello, F. Residents and urban green spaces: The case of Bari. Urban For. Urban Green. 2006, 4, 125-134. [CrossRef]

3. Xiao, Y.; Wang, D.; Fang, J. Exploring the disparities in park access through mobile phone data: Evidence from Shanghai, China. Landsc. Urban Plan. 2019, 181, 80-91. [CrossRef]

4. Banzhaf, H.S.; Walsh, R.P. Do people vote with their feet? An empirical test of Tiebout. Am. Econ. Rev. 2008, 98, 843-863. [CrossRef]

5. Antoniucci, V.; Marella, G. Immigrants and the city: The relevance of immigration on housing price gradient. Buildings 2017, 7, 91. [CrossRef]

6. Zivin, J.G.; Neidell, M. Environment, health, and human capital. J. Econ. Lit. 2013, 51, 689-730. [CrossRef]

7. Albouy, D. What are cities worth? Land rents, local productivity, and the total value of amenities. Rev. Econ. Stat. 2016, 98, 477-487. [CrossRef]

8. Song, Y.; Zhang, C. City size and housing purchase intention: Evidence from rural-urban migrants in China. Urban Stud. 2019, 57, 1866-1886. [CrossRef]

9. Martinico, F.; La Rosa, D.; Privitera, R. Green oriented urban development for urban ecosystem services provision in a medium sized city in southern Italy. Iforest-Biogeosciences For. 2014, 7, 385-395. [CrossRef]

10. Jim, C.Y.; Chen, W.Y. Impacts of urban environmental elements on residential housing prices in Guangzhou (China). Landsc. Urban Plan. 2006, 78, 422-434. [CrossRef]

11. Neema, M.N.; Ohgai, A. Multi-objective location modeling of urban parks and open spaces: Continuous optimization. Comput. Environ. Urban Syst. 2010, 34, 359-376. [CrossRef]

12. Song, Y.; Knaap, G. New urbanism and housing values: A disaggregate assessment. J. Urban Econ. 2003, 54, 218-238. [CrossRef] 
13. Wang, Y.; Wang, S.; Li, G.; Zhang, H.; Jin, L.; Su, Y.; Wu, K. Identifying the determinants of housing prices in China using spatial regression and the geographical detector technique. Appl. Geogr. 2017, 79, $26-36$. [CrossRef]

14. Morancho, A.B. A hedonic valuation of urban green areas. Landsc. Urban Plan. 2003, 66, 35-41. [CrossRef]

15. Broxterman, D.A.; Kuang, C. A revealed preference index of urban amenities: Using travel demand as a proxy. J. Reg. Sci. 2019, 59, 508-537. [CrossRef]

16. Trojanek, R.; Gluszak, M.; Tanas, J. The effect of urban green spaces on house prices in Warsaw. Int. J. Strateg. Prop. Manag. 2018, 22, 358-371. [CrossRef]

17. Ma, S.; Li, A. House price and its determinations in Beijing based on hedonic model. J. Civ. Eng. 2003, 36, 59-64.

18. Liu, T.; Hu, W.; Song, Y.; Zhang, A. Exploring spillover effects of ecological lands: A spatial multilevel hedonic price model of the housing market in Wuhan, China. Ecol. Econ. 2020, 170, 106568. [CrossRef]

19. Ross, S.L.; Yinger, J. Chapter 47 Sorting and voting: A review of the literature on urban public finance. Handb. Reg. Urban Econ. 1999, 3, 2001-2060.

20. Hsieh, C.; Moretti, E. Housing constraints and spatial misallocation. Am. Econ. J. Macroecon. 2019, 11, 1-39. [CrossRef]

21. Lee, C.; Liang, C.; Liu, Y. A comparison of the predictive powers of tenure choices between property ownership and renting. Int. J. Strateg. Prop. Manag. 2019, 23, 130-141. [CrossRef]

22. Diamond, R. Housing supply elasticity and rent extraction by state and local governments. Am. Econ. J. Econ. Policy 2017, 9, 74-111. [CrossRef]

23. Chen, A. China's urban housing reform: Price-rent ratio and market equilibrium. Urban Stud. 1996, 33, 1077-1092. [CrossRef]

24. Roback, J. Wages, rents, and amenities: Differences among workers and regions. Econ. Inq. 1988, 26, $23-41$. [CrossRef]

25. Zhou, X.; Qin, Z.; Zhang, Y.; Zhao, L.; Song, Y. Quantitative estimation and spatiotemporal characteristic analysis of price deviation in China's housing market. Sustainability 2019, 11, 7232. [CrossRef]

26. Xu, Z.; Zhang, Z.; Li, C. Exploring urban green spaces in China: Spatial patterns, driving factors and policy implications. Land Use Policy 2019, 89, 104-249. [CrossRef]

27. Stigsdotter, U.K.; Ekholm, O.; Schipperijn, J.; Toftager, M.; Kamper-Jørgensen, F.; Randrup, T.B. Health promoting outdoor environments-Associations between green space, and health, health-related quality of life and stress based on a Danish national representative survey. Scand. J. Public Health 2010, 38, 411-417. [CrossRef]

28. Krupka, D.J.; Donaldson, K.N. Wages, rents, and heterogeneous moving costs. Econ. Inq. 2013, 51, 844-864. [CrossRef]

29. Chen, W.Y.; Jim, C.Y. Resident motivations and willingness-to-pay for urban biodiversity conservation in Guangzhou (China). Environ. Manag. 2010, 45, 1052-1064. [CrossRef]

30. Oates, W.E. The effects of property taxes and local public spending on property values: An empirical study of tax capitalization and the Tiebout hypothesis. J. Political Econ. 1969, 77, 957-971. [CrossRef]

31. Jim, C.Y.; Chen, W.Y. Recreation-amenity use and contingent valuation of urban greenspaces in Guangzhou, China. Landsc. Urban Plan. 2006, 75, 81-96. [CrossRef]

32. Xu, C.; Dong, L.; Yu, C.; Zhang, Y.; Cheng, B. Can forest city construction affect urban air quality? The evidence from the Beijing-Tianjin-Hebei urban agglomeration of China. J. Clean. Prod. 2020, 264, 121607. [CrossRef]

33. Brasington, D.M.; Hite, D. Demand for environmental quality: A spatial hedonic analysis. Reg. Sci. Urban Econ. 2005, 35, 57-82. [CrossRef]

34. Szulczewska, B.; Giedych, R.; Borowski, J.; Kuchcik, M.; Sikorski, P.; Mazurkiewicz, A.; Stańczyk, T. How much green is needed for a vital neighbourhood? In search for empirical evidence. Land Use Policy 2014, 38, 330-345. [CrossRef]

35. Chengyi, C.; Wenzhong, Z.; Dongsheng, Z.; Xueli, L. Quantitative evaluation of human settlement environment and influencing factors in the Bohai Rim area. Prog. Geogr. 2017, 36, 1562-1570.

36. Doxiadis, C.A. Action for human settlements. Ekistics 1975, 40, 405-448.

37. McBean, G.; Ajibade, I. Climate change, related hazards and human settlements. Curr. Opin. Environ. Sustain. 2009, 1, 179-186. [CrossRef] 
38. Muttaqin, M.Z.; Alviya, I.; Lugina, M.; Hamdani, F.A.U. Indartik, Developing community-based forest ecosystem service management to reduce emissions from deforestation and forest degradation. For. Policy Econ. 2019, 108, 101938. [CrossRef]

39. Vujcic, M.; Tomicevic-Dubljevic, J. Urban forest benefits to the younger population: The case study of the city of Belgrade, Serbia. For. Policy Econ. 2018, 96, 54-62. [CrossRef]

40. Satyal, P.; Corbera, E.; Dawson, N.; Dhungana, H.; Maskey, G. Justice-related impacts and social differentiation dynamics in Nepal's REDD+ projects. For. Policy Econ. 2020, 117, 102203. [CrossRef]

41. Ushifusa, Y.; Tomohara, A. Productivity and Labor Density: Agglomeration Effects over Time. Atl. Econ. J. 2013, 41, 123-132. [CrossRef]

42. del Saz Salazar, S.; Menendez, L.G. Estimating the non-market benefits of an urban park: Does proximity matter? Land Use Policy 2007, 24, 296-305. [CrossRef]

43. Tajima, K. New estimates of the demand for urban green space: Implications for valuing the environmental benefits of Boston's big dig project. J. Urban Aff. 2003, 25, 641-655. [CrossRef]

44. La Rosa, D.; Privitera, R. Characterization of non-urbanized areas for land-use planning of agricultural and green infrastructure in urban contexts. Landsc. Urban Plan. 2013, 109, 94-106. [CrossRef]

45. La Greca, P.; La Rosa, D.; Martinico, F.; Privitera, R. Agricultural and green infrastructures: The role of non-urbanised areas for eco-sustainable planning in a metropolitan region. Environ. Pollut. 2011, 159, 2193-2202. [CrossRef]

46. Resosudarmo, I.A.P.; Tacconi, L.; Sloan, S.; Hamdani, F.A.U.; Alviya, I.; Muttaqin, M.Z. Indonesia's land reform: Implications for local livelihoods and climate change. For. Policy Econ. 2019, 108, 101903. [CrossRef]

Publisher's Note: MDPI stays neutral with regard to jurisdictional claims in published maps and institutional affiliations. 